\title{
Severe Acute Malnutrition in Tribal Under-Five children in Javvadu Hills, Tamil Nadu
}

\author{
Saravanakumar Palaniappan ${ }^{1 *}$, Elizabeth Varakumari Janakiraman ${ }^{2}$, Saradha Suresh $^{3}$ \\ ${ }^{1}$ Associate Professor, Department of Community Medicine, Kilpauk Medical College, Chennai, Tamil Nadu, India \\ ${ }^{2}$ Assistant Professor, Department of Community Medicine, Kilpauk Medical College, Chennai, Tamil Nadu, India \\ ${ }^{3}$ Research Expert, SAMARTH NGO, Chennai, Tamil Nadu, India
}

*Address for Correspondence: Dr. Saravanakumar Palaniappan, Associate Professor, Department of Community Medicine, Govt. Kilpauk Medical College, Chennai, Tamil Nadu, India

E-mail: drsaran77@gmail.com

Received: 17 Sep 2021/ Revised: 23 Nov 2021/ Accepted: 24 Dec 2021

\begin{abstract}
Background: Severe acute malnutrition (SAM) in under-5 children is an important public health problem that is associated with high mortality and long-term health consequences. Globally, 26 million children suffer from SAM, of these more than 8.1 million children are in India. National Family Health Survey-4 indicates a higher prevalence of SAM (7.5\%) in the general population than the previous report (6.4\%). Indeed the burden of malnutrition is expected to be higher among the tribal children in India. Hence this study aimed to explore the Severe Acute Malnutrition among the tribal under-five children in Javvadu Hills of Tamil Nadu.

Methods: A community-based cross-sectional survey was conducted among 450 tribal under-five children and mothers residing in Javvadu Hills in Thiruvannamalai District, Tamil Nadu from September 2019 to Feb 2020 using PPS-Cluster sampling technique with semi-structured questionnaire with anthropometric measurements. Data were analyzed using SPSS. Chi-square test and logistic regression were used.

Results: Out of 450 children, about 42(9.3\%) had weight-for-Ht (M<-3S.D.) suggestive of SAM. Among those with SAM, 71\% were females. About $66 \%$ had low birth weight, $79 \%$ were Anemic, $81 \%$ had calorie and protein inadequacy, $88.1 \%$ were partially immunized and $88 \%$ had food insecurity and $78 \%$ had the recurrent illness. Maternal illiteracy, poor awareness of nutrition, Food insecurity and poor access to health facilities were significant factors in SAM.

Conclusions: SAM is highly prevalent among tribal children, a serious threat to child survival and morbidity. Improving literacy, Socioeconomic status, nutritional awareness, food security, health-seeking behaviour will alleviate this public health problem.
\end{abstract}

Key-words: Nutritional awareness, Maternal illiteracy, Severe Acute Malnutrition, Tribal

\section{INTRODUCTION}

Malnutrition is characterized by a pathological condition resulting from the lack of energy as well as protein in different proportions, which can also be aggravated by recurrent infection Malnutrition includes being stunted (low height-for-age (HAZ), wasted (low weight-for-height (WHZ) and underweight (low weight-for-age) [1,2]. Globally Malnutrition affects one in every three people afflicting all age groups especially the poor and vulnerable and leads to approximately 10.4 million

\section{How to cite this article}

Palaniappan S, Janakiraman EV, Suresh S. Severe Acute Malnutrition in Tribal Under-Five children in Javvadu Hills, Tamil Nadu. SSR Inst. Int. J. Life Sci., 2022; 8(1): 2947-2952.

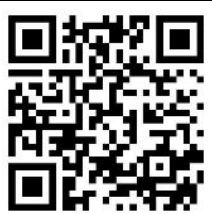

annual deaths in under-five in the developing world ${ }^{[3]}$. In developing countries, malnutrition is the most important risk factor for causing about 300,000 deaths annually directly or indirectly for more than $50 \%$ of all deaths in children ${ }^{[4,5]}$. As per the Global Hunger Index 2008, India scored 23.7 points and was placed in $66^{\text {th }}$ position among 88 countries ${ }^{[6,7]}$. Expert Committee in ICMR had stated in malnutrition report in 2010 suggests that about 39\% of Indian children had stunted growth and $42 \%$ suffered from underweight ${ }^{[8]}$.

Severe acute malnutrition (SAM) defined as severe wasting (weight-for-height $\mathrm{Z}$ score<-3.S.D.) with or without nutritional edema is a life-threatening condition requiring urgent intervention to prevent mortality, promote recovery and reduce morbidity like long term health consequences ${ }^{[8]}$. As per NFHS3, the reported prevalence of SAM in India was $7.9 \%{ }^{[9]}$ and NFHS4, 
reported $7.4 \%$ which is a quite significant problem in the general population itself ${ }^{[10]}$. Indeed the Severe Acute Malnutrition is a serious issue in the tribal population who are already a vulnerable sector of the nation. India is home to almost half of the tribal population distributed globally ${ }^{[11}$. Tribal people are social groups characterized by more superstitious, illiterate with traditional, distinctive culture and beliefs with socioeconomic backwardness accounting for $8.2 \%$ of the total population ${ }^{[11,12]}$. Kshatriya et al. ${ }^{[13]}$ and Dutta et al. ${ }^{\text {[14] }}$ had reported widespread prevalence of Under-nutrition among the tribal children in the Himalayas, Coastal and Desert ecology in India. Samiran et al. ${ }^{[15]}$ also reported that malnutrition is highly prevalent in tribal children under the age of five in West Bengal. There is a paucity of data on Under-nutrition and SAM in tribal under-five children in Tamil Nadu ${ }^{[16]}$, which is home to a tribal population of 7, 94,697 as per Census $2011^{[17,18]}$. Hence this study was designed to assess the prevalence of malnutrition among the under-five children in Javvadu Hills in Thiruvannamalai District of Tamil Nadu, India.

\section{MATERIALS AND METHODS}

A community-based cross-sectional survey was planned to assess the under-nutrition among the tribal under-five children of sample size 450 based on Probability Proportional sampling (PPS) Cluster sampling technique in tribal villages in Javvadu Hills of Thiruvannamalai District in Tamil Nadu chosen at random from September 2019 to February 2020.

This district has a tribal population of 46,440 who have settled in Javvadu hills with 118 tribal villages with about 4814 children under the age of five years. About 30 clusters with 15 children in each under the age of five were included in this study that was drawn by simple random sampling in each cluster using the under-five register maintained by the village health nurse. Children with developmental delay, documented chronic systemic diseases, metabolic disorders on special diets were excluded from the study.

Mothers were interviewed with a semi-structured questionnaire in Tamil, which included sociodemographic details, Maternal history on antenatal, intra-natal, postnatal details, breastfeeding and complementary feeding practices, Immunization, nutrition, food security based on USAID (HFIAS) ${ }^{18}$, healthseeking behaviour and case format for clinical and anthropometric assessment of children and Hemoglobin estimation. The study on Severe Acute Malnutrition among the tribal under-five children is a part of the large cross-sectional survey, which is presented as follows. SAM was defined as weight for height below-3 S.D., Mid arm circumference $<11.5 \mathrm{~cm}$.

Ethical Approval- Prior permission from Institutional Review Board in Madras Medical College, Chennai was obtained and permission from public health authorities \& local tribal leaders.

Statistical Analysis- Data was entered in MS Excel, analyzed in SPSS version 16 with descriptive statistics like Mean, Proportion and inferential statistics as Chi-Square test and logistic regression.

\section{RESULTS}

This community based cross-sectional study on overall under-nutrition among 450 tribal under-five children in Javvadu hills in Thiruvannamalai District of Tamil Nadu revealed a high prevalence of Severe Acute Malnutrition as $9.3 \%$ (42 children) of whom $71 \%$ were females. The mean age of children with SAM was $3.8+/-0.89$. The majority of the children were more than 3 years of age.

Table 1 show the socio-demographic details wherein all were of lower socio-economic class. About $66 \%$ of these children were born with low birth weight (birth $w t .<2.5 \mathrm{~kg}$ ). There was poor awareness among the mothers of these children regarding ideal infant feeding practices and ideal nutrition during the age of under-five.

Table 1: Socio-demographic details of children with SAM

\begin{tabular}{|c|c|c|}
\hline S.No & Variables & $\mathrm{N}=42(\%)$ \\
\hline 1. & Age more than 3 years & $29(69)$ \\
\hline \multirow[t]{2}{*}{2.} & Male & $12(29)$ \\
\hline & Female & $30(71)$ \\
\hline 3. & Higher-order birth (3 and >) & $28(66)$ \\
\hline 4. & Maternal illiteracy & $34(81)$ \\
\hline 5. & Open defecation practices & $35(83)$ \\
\hline 6. & Unsafe drinking water & $31(74)$ \\
\hline 7. & Barefoot walking & $37(88)$ \\
\hline
\end{tabular}

$\mathrm{N}=$ Frequency

Table 2 describes the nutritional determinants of Severe Acute Malnutrition. About $88 \%$ of them were not exclusively breastfed and only $45 \%$ had complementary 
feeding started at 6 to 8 months of age. There was a high prevalence of calorie and protein inadequacy in the diet of these children, which was about $81 \%$. Only $11 \%$ of the children with Severe Acute Malnutrition had utilized ICDS for supplementary nutrition, which was due to the long distance of the ICDS centre from their residence.

Table 2: Nutritional determinants of SAM

\begin{tabular}{|c|c|c|}
\hline S.No & Variables & $\mathbf{N}=\mathbf{4 2}(\%)$ \\
\hline 1. & Exclusive breastfeeding & $5(12)$ \\
\hline 2 & $\begin{array}{c}\text { Complementary feeding 6 to } 8 \\
\text { months }\end{array}$ & $19(45)$ \\
\hline 3 & $\begin{array}{c}\text { Calorie and protein } \\
\text { inadequacy }\end{array}$ & $34(81)$ \\
\hline 4 & $\begin{array}{c}\text { ICDS nutritional supplements } \\
- \text { utilization }\end{array}$ & $5(11)$ \\
\hline 5 & Vitamin A supplementation & $9(21)$ \\
\hline
\end{tabular}

\section{$\mathrm{N}=$ Frequency}

Table 3 describes the prevalence of Anemia and the severity, where about $79 \%$ were anaemic of which the majority were girls. The severity of anaemia also was found to be higher in girls. Clinically about $80 \%$ had pallor, $66 \%$ had Bitot spots, $88 \%$ had dental caries and $67 \%$ had impetigo, unclean nails and dress.

Table 3: Prevalence of Anemia among the tribal children

\begin{tabular}{|c|c|c|c|c|}
\hline $\begin{array}{c}\text { Hemoglobin } \\
\text { (gm/dl) }\end{array}$ & $\mathrm{n}=\mathbf{4 2}$ & Male & Female & $\begin{array}{c}\text { Percentage } \\
\text { (\%) }\end{array}$ \\
\hline$>11$ & 9 & 3 & 6 & 21 \\
\hline $9-11$ & 18 & 5 & 13 & 43 \\
\hline $7-9$ & 11 & 4 & 7 & 26 \\
\hline$<7$ & 4 & 1 & 3 & 10 \\
\hline
\end{tabular}

$\mathrm{n}=$ Frequency

Table 4 shows the health seeking behaviour of the mothers for their children wherein about $88 \%$ were partially immunized for the age and poor utilization of health services provided by the Primary Health centre in the Hills due to difficult terrain and poor access to transport facilities with a high prevalence of recurrent infections like respiratory tract infections and Diarrhoea. Only $21 \%$ of children were monitored for weight gain by the health personnel and regular deworming was done in $16 \%$ of these children with Severe Acute Malnutrition.

Table 4: Health seeking behaviour of the mothers of children with SAM

\begin{tabular}{|c|c|c|}
\hline S.No & Variables & $\mathbf{N = 4 2 ( \% )}$ \\
\hline 1. & Partial Immunization & $37(88)$ \\
\hline 2. & $\begin{array}{c}\text { Recurrent respiratory } \\
\text { infections ( >3 episodes in } \\
\text { past 3 months) }\end{array}$ & $27(64)$ \\
\hline 3. & $\begin{array}{c}\text { Recurrent Diarrhoea (>3 } \\
\text { episodes past 3 months) }\end{array}$ & $33(78)$ \\
\hline 4. & $\begin{array}{c}\text { Monitoring by health } \\
\text { Personnel }\end{array}$ & $9(21)$ \\
\hline 5 & Regular deworming & $7(16)$ \\
\hline
\end{tabular}

\section{$\mathrm{N}=$ Frequency}

The major determinants of SAM in these children were the age of children ( $>3$ years of age), female gender, higher-order birth ( 3 and above), inadequate nutrition, food insecurity in family and under-utilization of health services with statistical significance as described in Table 5.

Table 5: Determinants of SAM

\begin{tabular}{|c|c|c|}
\hline S.No & Determinants & OR (CI) \\
\hline 1. & Age of child 3 \& above & $2.4(1.22-3.12)$ \\
\hline 2. & Female Gender & $3.1(2.12-4.11)$ \\
\hline 3. & Higher-order birth & $1.2(1.01-2.38)$ \\
\hline 4. & Inadequate Nutrition & $3.84(2.19-5.65)$ \\
\hline 5. & Family Food insecurity & $1.8(1.16-2.82)$ \\
\hline 6. & Under-utilization of Health & $2.12(1.41-3.58)$ \\
& services & \\
\hline
\end{tabular}

OR (CI)= Odds Ratio (Confidence Interval)

\section{DISCUSSION}

Under nutrition renders the children under the age of five years at a greater risk of acquiring recurrent infections, which may be associated with delayed recovery, stunting of growth potential, low efficiency in a future life as well as mortality ${ }^{[1,2]}$. Malnutrition is the leading cause of almost half of all deaths in under-five 
age worldwide, which is a preventable one ${ }^{[3]}$. In India, also almost $42 \%$ of children under the age of five suffer from under-nutrition particularly Severe Acute Malnutrition (SAM) accounts for $7.4 \%$, which needs emergency attention to prevent deaths ${ }^{[10]}$. In tribal populations, SAM is reported to be higher which needs to be explored. This study conducted among the tribal under-five children in Javvadu hills of Thiruvannamalai district identified the prevalence of SAM to be $9.3 \%$ (CI8.1 to 10.4 ), which was higher than the national figures ${ }^{[10]}$. Kshatriya et al. ${ }^{[13]}$ reported the prevalence of SAM to be $8.1 \%$ among the tribal children in the Himalayan region in North India. SAM was observed to be higher as age advanced in the under-five population may be due to mismatch of need and intake of nutrients in the diet. Dutta et al. ${ }^{[14]}$ also reported the prevalence of undernutrition to increase with advancing age in the tribal children in Garhwal Himalayas attributed to demand and supply mismatch in nutrients. Rao et al. ${ }^{[19]}$ had stressed that malnutrition sets in if nutritional demand was not met as age advanced from infancy to five years of age in their study among the tribal children in Andaman and Nicobar. Also, the severity of under-nutrition was found higher at the age of 5 years in tribal preschool children as reported by Rekha Rachel Philip et al in the Wayanad district of Kerala ${ }^{[20]}$.

In this study, Severe Acute Malnutrition was observed to be higher in female children than males as reported by Sahu et al. ${ }^{[21]}$; Soudarssanane et al. ${ }^{[22]}$ in tribal children in India. Also, about $79 \%$ of children were suffering from Anemia in this study, which is higher than that reported as $62 \%$ by Venkat et al. ${ }^{[23]}$ in their study. Anaemia is indeed an important public health problem among the tribal children in the under-five population which not only affects their growth and development but is also an important risk factor for recurrent infections even death $[24,25]$. Practices like open defecation and barefoot walking were observed to be high in our study which is indeed an important risk factor for worm infestation and anaemia in the under-five age group as also reported by Sreedhar et al. ${ }^{[26]}$.

In this study, we observed that challenges like the low prevalence of exclusive breastfeeding, delayed complementary feeding practices, poor awareness among the mothers on nutritional foods thereby high prevalence of calorie and protein inadequacy in the regular diet of these children. Soudarssanane et al. ${ }^{[22]}$ also reported that awareness on giving colostrum, exclusive breastfeeding, timely complementary feeding and good nutrition was poor among the tribal mothers thereby an important determinant in the high prevalence of under-nutrition among the tribal children. We also observed that the mothers failed to utilize the ICDS services regularly due to the distance of ICDS centres from their residence which was mostly in difficult hilly terrain also immunization services, regular deworming and monitoring of health status of these children were also under-utilized due to the inaccessibility of the health care centre. Meshram II et al also reported that utilization of ICDS services was observed to be low among the tribal mothers in their study secondary to inaccessibility to health services ${ }^{[27]}$. Rao et al. ${ }^{[28]}$ also reported that recurrent infections and poor monitoring of nutrition of the tribal children be an important factor in the management of under-nutrition among tribal preschool children. The limitations of this study are as follows like larger sample size involving still more difficult areas of the tribal settlement; qualitative research on the beliefs of the mothers will throw more light into this public health problem. Also, we have not investigated for Hemoglobinopathies and other investigations for undernutrition which will be the future scope of research.

Thus the major determinants of severe acute malnutrition among the tribal under-five children observed in this study were low birth weight, higherorder birth, inadequate nutrition, food insecurity in the family and under-utilization of health services. Dolla et al. ${ }^{[29]}$ also reported that higher-order birth, low birth weight, low prevalence of exclusive breastfeeding and poor maternal awareness on nutrition were important determinants in under-nutrition which have to be prevented at the primary care level right from antenatal care throughout infancy to five years to prevent the malnutrition in this age group. Reddy et al. ${ }^{[30]}$ also reported that a holistic approach is needed to combat malnutrition among the tribal under-five children. Hence we need to focus on primary care on improving antenatal care, awareness on exclusive breast feeding, adequate nutrition, regular monitoring of health status and utilization of all health services provided to the under-five children to the fullest extent to prevent malnutrition and mortality due to severe acute malnutrition among this vulnerable sector. 


\section{CONCLUSIONS}

Severe Acute Malnutrition is highly prevalent among tribal children under the age of five years than the general population which indeed renders the child succumb to recurrent infections as well as a serious threat to survival. There is an urgent need to focus on improving socio-economic status, maternal literacy, awareness on nutrition, food security, accessibility to health services and health-seeking behaviour among this tribal population to alleviate the major public health problem of Malnutrition and thereby reduce the morbidity and mortality in the under-five population.

Furthermore, studies that will focus on the health of the tribal population as a whole, their socio-cultural beliefs, awareness of all the health services provided by the public health sector and difficulties in utilization of Primary health care are needed towards the long term prevention of under-nutrition in this vulnerable sector of the society.

\section{ACKNOWLEDGMENTS}

We extend our gratitude to the public health authorities, health personnel, who had helped in accessing the tribal population and all the mothers with their children, who had participated in this study.

\section{CONTRIBUTION OF AUTHORS}

Research concept- Saravana Kumar $P$

Research design- Saravana Kumar $P$

Supervision- Saravana Kumar $P$

Data collection- Saravana Kumar $P$

Data analysis and Interpretation- Elizabeth Varakumari J Literature search- Elizabeth Varakumari J

Writing article- Elizabeth Varakumari J

Critical review-Saradha Suresh

Article editing- Saradha Suresh

Final approval-Saradha Suresh

\section{REFERENCES}

[1] Black RE, Alderman H, Bhutta ZA. Maternal and Child Nutrition: Building momentum for impact. Lancet, 2008; 382: 372-75.

[2] Horton JR. Lo S. Child Malnutrition. A quintessential sustainable developmental goa. Lancet 2013; 371: 243-55.

[3] Robert. Joint child Malnutrition estimates. WHO. Levels Trends, 2017; 292(9): 23-25.
[4] Ashima G. State-wise Malnutrition analysis in IndiaFindings from NFHS III. Int J Sci Res., 2016; 5(4): 482483.

[5] Manary MJ, Sandige HL. Management of acute moderate and severe childhood malnutrition. BMJ, 2008; 337: 1227-30.

[6] Bhutta ZA, Ahmed T, Black RE, Cousens S, Dewey K, et al. What works? Interventions for maternal and child under-nutrition and survival. Lancet, 2008; 371(9610): 417- 40.

[7] Black RE, Allen LH, Bhutta ZA, Caulfield LE, De Onis $M$, et al. Maternal and child under-nutrition: global and regional exposures and health consequences. Lancet 2008; 371(9608): 243-60.

[8] ICMR Expert Committee. Nutrient requirements and recommended dietary allowances for Indians. A report of the expert group of the Indian Council of Medical Research. $2^{\text {nd }}$ ed., Vol. 2010. New Delhi: Indian Council of Medical Research, 2010.

[9] International Institutes of Population Sciences (IIPS), Mumbai. Final report of the National Family Health Survey-3. [Accessed on June 25, 2012]. Available from: www.nfhsindia.org/nfhs3.html.

[10]International Institute for Population Sciences. National Family Health Survey (NFHS-4). Mumbai: International Institute for Population Sciences, 2016.

[11]Ministry of Tribal Affairs. Government of India. Scheduled tribes: Available at: //http://tribal.nic.in/content/IntroductionScheduledt ribes.aspx. Accessed at 7 May 2016.

[12]Thurston E. Castes and Tribes of Southern India. 6 vols. Volume 4. Madras: Government Press, 2009; pp. 408.

[13]Kshatriya GK, Ghosh A. Under-nutrition among the tribal children in India: tribes of Coastal, Himalayan and Desert ecology. Anthropol Anz., 2008; 66(3): 355-63.

[14]Dutta A, Pant K, Puthia R, Sah A. Prevalence of Under-nutrition among the children in the Garhwal Himalayas. Food Nutr Bull., 2009; 30(1): 77-81.

[15]Samiran B, Chhanda M. Prevalence of undernutrition among KoraMudi children aged 2-13 years in PaschimMedinipur District, West Bengal, India World J Pediatr, 2011; 7(1): 243-45.

[16]Draft on Nutritional status of Tribals in Thiruvannamalai /http//ICDS/gov.T.N. report. 
[17]Census India 2011. gov.in/Table_Published/ Tables_published.html, 2012.

[18]Coates J, Anne S, Paula B. Household Food. Insecurity Access Scale (HFIAS) for. Measurement of Household Food. Access: Indicator Guide.Version3.Washington. USA. USAID2007. www.fao.org/ fileadmin/user upload/eufao-fsi4dm/doc-training/hfias.pdf.

[19]Rao VG, Sugunan AP, Murhekar MV, Sehgal SC. Malnutrition and high childhood mortality among the Onge tribe of the Andaman and Nicobar Islands. Public Health Nutr., 2006; 9(1): 19-25.

[20]Philip RR, Vijayakumar K, Indu PS, Shrinivasa BM, Sreelal TP, et al. Prevalence of undernutrition among tribal preschool children in Wayanad district of Kerala. Int J Adv Med Health Res., 2015; 1(2): 33-38.

[21]Sahu T, Sahani NC, Patnaik L. Childhood Anemia- A study in tribal area of Mohana Block in Orissa. Ind J Com Med., 1: 2007: 43-45.

[22]Soudarssanane MB, Thiruselva K. Overcoming problems in the practice of Public Health among the tribals of India. Ind J Com Med., 2009; 34(4): 283-87.

[23]Venkat NK. Tribal health problems in India: An overview. Int J Mult Dis Adv Res Trends, 2015; 2: 4954.
[24]Rao TV, Vijay T. Malnutrition and Anemia in tribal Pediatric population of Purnia district (Bihar), Indian Pediatr., 2006; 43: 181-83.

[25] Kotecha PV. Nutritional anemia in young children with focus on Asia and India. Ind J Com Med., 2011; 36: 8-16.

[26]Sreedhar T, et al. Study of Anemia in Tribal childrenA prospective study. J Dental Med Sci., 2016; 15: 1-5.

[27]Meshram II, Arlappa N, Balakrishna N, et al. Trends in the prevalence of under-nutrition, nutrient $\&$ food intake and predictors of under-nutrition among under-five year tribal children in India. Asia Pac J Clin Nutr., 2012; 21(4): 568-76.

[28]Rao VG, Yadav R, Dolla CK, Kumar S, et al. Undernutrition \& childhood morbidities among tribal preschool children. Indian J Med Res., 2005; 122: 4347.

[29] Dolla CK, Meshram P, Shrivatsava P, Karforma C, Das S. Nutritional status of Kodaku Pre-school children in Central India. J Hum Eco., 2005; 17(3): 229-32.

[30]Reddy DC, Singh K, et al. Epidemiology of Nutritional deficiency disorders among tribal pre-school children around Manikpur, Banda district, Uttar Pradesh. India J Prev Soc Med., 1984; 15: 57-62.

\section{Open Access Policy:}

Authors/Contributors are responsible for originality, contents, correct references, and ethical issues. SSR-IIJLS publishes all articles under Creative Commons Attribution- Non-Commercial 4.0 International License (CC BY-NC). https://creativecommons.org/licenses/by-nc/4.0/legalcode (c) (1) (9) 